\title{
Pengenalan Wajah Menggunakan Metode Fisherface
}

\author{
Riko Arlando S aragih \\ Jurusan Teknik Elektro Universitas Kristen Maranatha \\ Jl. Prof. Drg. Suria Sumantri 65, Bandung, Indonesia \\ Phone: +62222012186 Fax: +62222015154 \\ E-mail: riko_saragih@yahoo.com
}

\begin{abstract}
ABSTRAK
Tulisan ini menjelaskan tentang pengenalan wajah manusia dengan metode fisherface untuk mengidentifkasikan seseorang. Keluarannya adalah dikenali atau tidaknya sebuah gambar masukan sebagai salah satu individu pada database. Terdapat empat langkah utama dalam metode pengenalan wajah ini, yaitu deteksi wajah, perhitungan PCA(Principal Component Analysis), perhitungan FLD (Fisher's Linear Discriminant), dan klasifikasi. Dalam modul deteksi wajah, segmentasi wama dilakukan untuk mendapatkan bagian dari gambar masukan yang memiliki wamakulit. Modul perhitungan PCA dan modul perhitungan FLD digunakan untuk membentuk satu set fisherface dari suatu training set yang digunakan. Selunuh gambar wajah dapat direkonstuksi dari kombinasi fisherface dengan bobot yang berbeda-beda. Pada modul terakhir, dilakukan proses pengenalan identitas dengan cara membandingkan bobot fisherface yang dibutuhkan untuk merkonstruksi gambar masukan terhadap gambar pada training set. Perhitungan bobot dilakukan dengan metode jarak Euclidian. Pengujian dilakukan terhadap 66 gambar masukan dan tingkat keberhasilan pengenalan wajah sebesar $81,82 \%$.
\end{abstract}

Kata kunci : fisherface, deteksi wajah, PCA, FLD, klasifikasi, jarak Euclidian.

\begin{abstract}
This paper describes human identification using fisherface method to identify someone. Theoutput is whether recognized or not an input image as an individual in the database. There are four main stages for this method, mainly face detedion, PCA (Principal Component Analysis) calculation, FLD (Fisher's Linear Analysis) calculation and dassification stage. In face detection stage, color thresholding is used to segment pixels that contain skin color. PCAcalaulation and FLD calaulation stages are used to form a set of fisherfaces from a training set or database that will be used. All faceimages can be reconstructed from the combination of fisherfaces with different weights for each faceimage. The last stage, dassification stage, is to identify the input image by comparing the weight of fisherface required to reconstruat the input face towards face images in the training set. The weight calculation is done by using Euclidian distancemethod. The simulations are done for 66 input images and the successful recognition rate is about $81.82 \%$.
\end{abstract}

Keywords: fisherface, face detection, PCA, FLD, classification, Euclidian distance.

\section{PENDAHULUAN}

Wajah merupakan salah satu ukuran fisiologisyang paling mudah dan sering digunakan untuk membedakan indentitas individu yang satu dengan yang lainnya. Manusia dapat membedakan wajah antara orang yang satu dengan yang lainnya dan mengingat wajah seseorang dengan cepat dan mudah. Oleh karena itu, face recognition merupakan salah satu teknologi biometrics yang banyak dipelajari dan dikembangkan oleh para ahli.

Kesulitan dalam pembuatan prosesface recognition terutama adalah karena kekompleksan dari kondisi wajah, yaitu alam hal kualitas gambar yangditang-

Catatan: Diskusi untuk makalah ini diterima sebelum tanggal1 Juni2007. Diskusi y ang lay ak muat akan diterbitkan pada Jurnal Teknik Eleltro volume 7, nom or 1, Septem ber 2007. kap, dari segi warna, pencahayaan, hingga posisi gambar yang tertangkap, maupun dalam hal pert bahan geometrinya. Oleh karena itu dalam tulisan ini akan diujikan metode fisherface untuk melakukan pengenalan wajah.

\section{TINJAUAN PUSTAKA}

Face recognition atau pengenalan wajah adalah salah satu teknik identifikasi teknologi biometrik dengan menggunakan wajah individu yang bersangkutan sebagai parameter utamanya. Secara garis besar proses pengenalan wajah terdiri dari tiga prosesutama [1], yaitu:

1. Deteksi wajah (face detection).

2. Ektraksi ciri/wajah (face/feature extraction).

3. Pengenalan wajah (face recognition). 
Secara umum, teknik dan metode dalam pengenalan wajah dapat dikelompokan ke dalam tiga pendekatan berdasarkan data yang dibutuhkannya [1], yaitu: 1. Pendekatan holistik.

Pada pendekatan holistik, seluruh bagian atauciriciri global wajah digunakan sebagai data masukan untuk pengenalan wajah.

Cont oh: eigenface, fisherface, nearest feature line (NFL), dan support vector machine (SVM).

2. Pendekatan feature-based.

Pada pendekatan feature-based, wajah terbagi berdasarkan ciri-ciri lokal wajah sepertihidung mulut, mata, dan lainnya yang kemudian digunakan sebagai data masukan. Contoh : Hidden Markov Model dan Dynamic Link Architecture.

3. Pendekatan hybrid.

Pendekatan hybrid menggunakan seluruh bagian wajah dan ciri-ciri lokal wajah sebagai data masukan. Contoh : modular eigenface dan hybrid local feature.

\section{METO DE FISHERFAC E}

Pengenalan wajah yang akan direalisasikan terbagike dalam empat modul utama. Diagram blok yangakan direalisasikan terlihat pada Gambar 1.

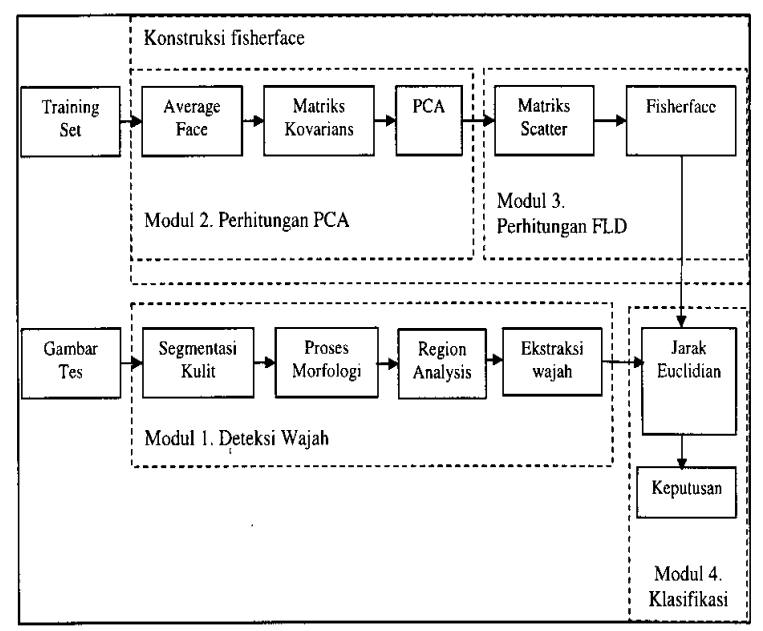

Gambar 1. Diagram Blok yang akan Direalisasikan

\section{Deteksi Wajah (Face Detection)}

Salah satu kunci sukses dalam pengenalan wajah adalah deteksi wajah yang akurat karena gambar wajah yang terdeteksi akan sangat mempengaruhi dalam proses pengenalannya [4]. Langkah pertama pada pengenalan wajah secara otomatis adalah mendeteksi keberadaan wajah dari gambar masukan. Setelah wajah terdeteksi, tugas feature extraction adalah untuk memperoleh ciri-ciri dari wajah yang diperlukan pada klasifikasi wajah. Bergantungpada tipe pengenalan wajahnya, ciri-ciriyang diperlukan dapat berupa ciri-ciri lokal wajah seperti hidung mata, mulut, dan lainnya, maupun ciri-ciri global wajah (seluruh bagian wajah). Metode fisherface menggunakan seluruh bagian wajah sebagai data dalam pengenalannya.

\section{Segmentasi Warna Kulit}

Proses yang dilakukan pertama kali pada algoritma deteksi wajah yang digunakan adalah membuang sebanyak mungkin bagian bukan wajah dari gambar input. Hal ini dapat dilakukan dengan memberikan batasan pada nilai intensitas warna (color thresholding) pada gambar input karena pada dasarnya seluruh manusia memiliki range atau cakupan nilai warna (chrominance value) yanghampir sama untuk warna kulitnya. Yang membedakannya adalah variasi pada nilai intensitas cahayanya (luminance value) [3]. Akibatnya, jika nilai chrominance dan luminance dapat dipisahkan dari gambar dan kemudian dilakukan pembatasan nilai intensitas pada komponen chrominance, akan didapat bagian yangmerupakan bagian berwarna seperti kulit (skin like-hood) dari gambar input.

Salah satu cara memisahkan nilai intensitascahaya dari komponen warna gambar masukan adalah dengan mentransformasi komponen warna gambar masukan yang merupakan gambar berwarna(RGB) ke dalam komponen warna $\mathrm{YCbCr}$ (Iluminance, Chrominance-blue, Chrominance-red). Jika pada komponen warna RGB masih terdapat informasi mengenai intensitas pencahayaan pada setiap komponen warnanya (Red, Green, Blue), untuk komponen warna $\mathrm{YCbCr}$, komponen $\mathrm{Cb}$ dan $\mathrm{Cr}$ merupakan komponen warna yang bebas dari intensitas cahaya, karena seluruh informasi mengenai cahaya pada gambar disimpan pada komponen Y. Persamaan transformasi komponen warna RGBke YCbCr adalah [2]:

$$
\left[\begin{array}{l}
Y \\
C b \\
C r
\end{array}\right]=\left[\begin{array}{ccc}
0.275 & 0.504 & 0.098 \\
0.148 & -0.291 & 0.439 \\
0.439 & -0.368 & -0.071
\end{array}\right] \cdot\left[\begin{array}{c}
R \\
G \\
B
\end{array}\right]+\left[\begin{array}{c}
16 \\
128 \\
128
\end{array}\right]
$$

Antara nilai $\mathrm{Cb}$ dan $\mathrm{Cr}$ terdapat korelasi yang menunjukkan piksel pada gambar yang memiliki warna kulit seperti yang terlihat pada Gambar 2 .

Gambar 3 menunjukkan nilai komponen Cbdan $\mathrm{Cr}$ pada seluruh bagian gambar dan nilai yang hanya menunjukkan bagian kulit saja. 


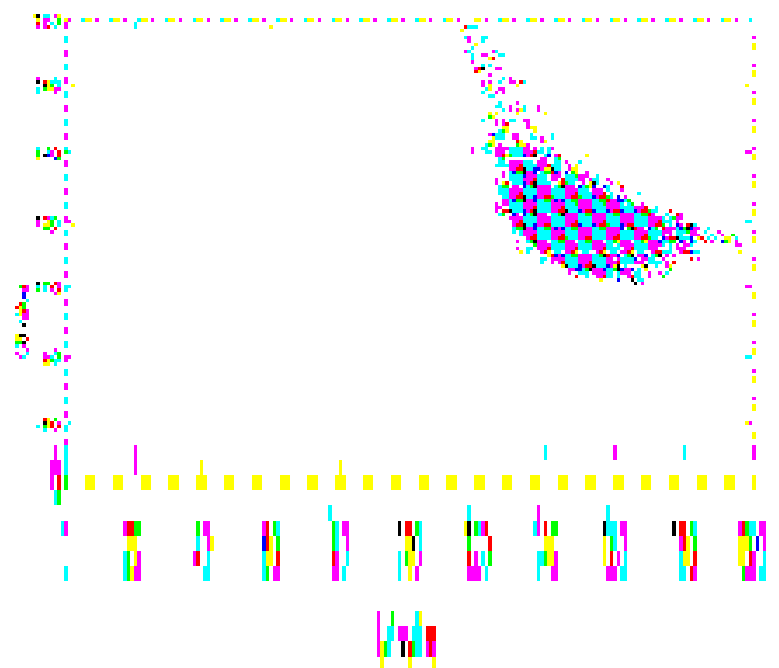

Gambar 2. Korelasi Antara Nilai $\mathrm{Cb}$ dan $\mathrm{Cr}$ yang Menunjukkan Warna Kulit[3]

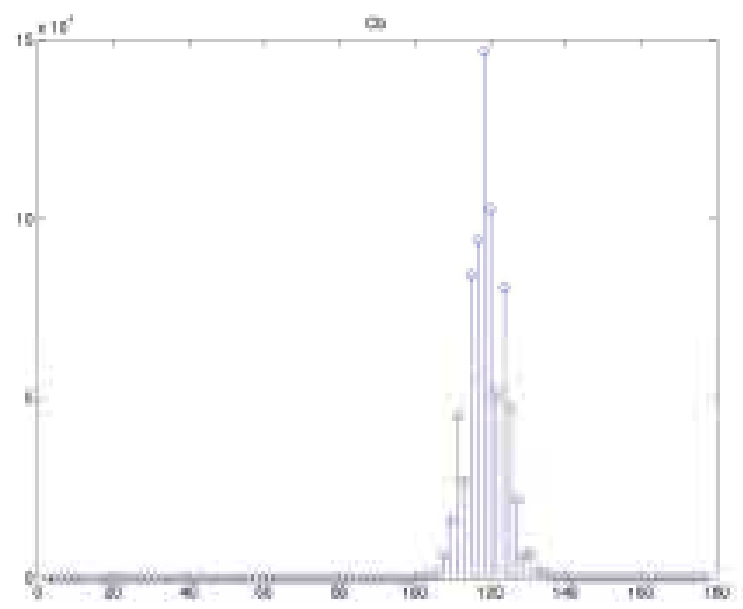

Gambar 3a. Komponen Cb Bagian Kulit

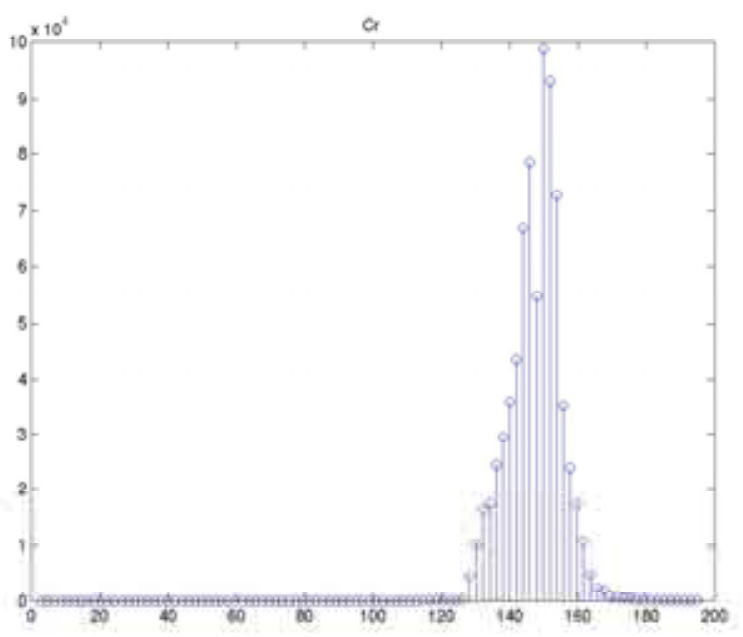

Gambar 3b. Komponen Cr Bagian Kulit

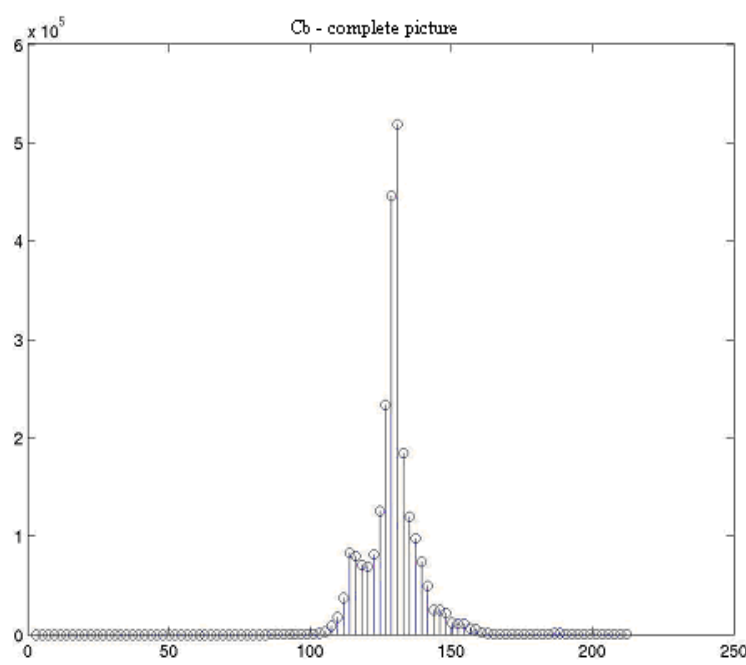

Gambar 3c. Komponen Cb Gambar Lengkap

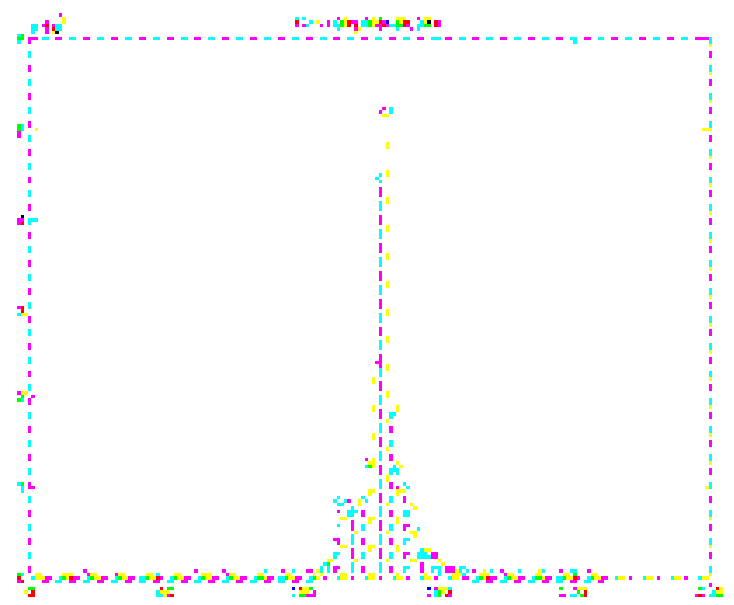

Gambar 3d. Komponen Cr Gambar Lengkap

Dari Gambar 3, bisa didapatkan satu nilai batas maksimum dan minimum untuk masing-masing komponen $\mathrm{Cb}$ dan $\mathrm{Cr}$ yang dapat menunjukkan bagian at au piksel yang memiliki warna kulit dari gambar input, yaitu [2]:

$$
\begin{aligned}
& 140<\mathrm{Cr}<165 \\
& 105<\mathrm{Cb}<135
\end{aligned}
$$

\section{Proses Morfologi}

Hasil dari proses segmentasi kulit adalah topeng (mask) yang berupa gambar hitam putih (binary image) yang menunjukkan bagian kulit dari gambar masukan. Akan tetapi topeng hasil segmentasikulit masih terdapat noise dan potongan dari beberapa benda lainnya pada gambar, seperti latar belakang gambar. Oleh karena itu, perlu dilakukan beberapa tahapan proses morfologi untuk membersihkan gambar dari noise dan potongan tersebut. 
Teknik morfologi dapat dilakukan untuk suatu gambar biner maupun gambar pada level grayscale (abu-abu). Untuk gambar biner, piksel berwarna putih bernilai biner " 1 " (ON) dan piksel berwarna hitam bernilai biner " 0 " (OFF).

Proses morfologi untuk gamber biner adalah proses erosi dan dilasi. Proses erosi membuang piksel dari gambar atau ekivalen dengan membuat piksel ON menjadi OFF, yaitu piksel putih yangmelekat pada daerah background, sehingga akan menyebabkan piksel putih berkurang luasnya (shrinking) dengan tujuan untuk menghilangkan piksel yangmerupakan noise pada topeng. Prosesdilasi merupakan kebalikan dari proses erosi, membuat pikselOFF menjadi ON, sehingga akan menyebabkan piksel putih bertambah luasnya (growing). Tujuan dilakukan prosesdilasi adalah karena saat proses erosi dilakukan pada topeng, daerah yang merupakan kulit juga ikut mengalami shrinking sehingga perludilakukan suatu proses yang mengembalikan daerah tersebut agar bagian wajah nantinya akan terdeteksi dengan benar.

\section{Region Analysis}

Gambar topeng hasil proses morfologi akan tetap terdapat bagian bukan wajah yangmerupakan bagian tubuh lainnya seperti tangan dan bagian lainnya yang memiliki intensitas warna yangmenyerupai intensitas warna kulit. Pada proses region analysis akan dianalisa bagian-bagian tersebut untuk mendapatkan satu bagian yang merupakan bagian wajah, yaitu dengan menghitung nilai Euler dari tiap-tiap bagian yang terdapat pada topeng. Nilai Euler pada gambar biner adalah selisih antara region (daerah yang memiliki nilai piksel 1) dengan hole (daerah yang memilki nilai piksel 0) yangada pada region tersebut. Pada umumnya untuk wajah manusia setidaknya akan memiliki satu region dan tiga buah hole pada region tersebut yang menunjukkan sepasangmata dan satu mulut.

\section{Ekstraksi Wajah}

Setelah didapat satu bagian yang merupakan wajah, proses selanjutnya adalah mengambil (cropping) wajah tersebut dari gambar input dengan ukuran yang sesuai dengan posisi wajah pada gambar topengdan mengubah ukurannya menjadi ukuran yang sama dengan ukuran gambar wajah pada training set yang digunakan untuk pengenalan wajah.

\section{Perhitungan PCA}

Konstruksi fisherface adalah pembuatan suatuset fisherface dari suatu set gambar training dengan menggunakan perhitungan Principal Component Analysis (PCA) dan Fisher's Linear Discriminant (FLD). Perhitungan PCA dilakukan dengan langkahlangkah sebagai berikut:

1. Mengambil satu set gambar trainingdan kemudian mentransformasikan setiap gambar tersebut menjadi vektor kolom, sehingga akan didapat satu matriks yang tiap kolomnya mewakili gambar yang berbeda, face space $(\Gamma)$.

2. Membentuk average face $(\Psi)$, yaitunilai rata-rata dari seluruh gambar wajah pada training set, dan mengurangi seluruh gambar pada training set terhadap average face untuk mencari deviasinya $(\phi)$.

$$
\phi=\Gamma-\Psi \text {. }
$$

3. Menghitung matriks kovarian (A), yaitudengan melakukan operasi perkalian transpose dari training set yang telah dinormalisasikan.

$$
A=\phi^{T} \phi \text {. }
$$

4. Menghitung nilai eigen $(\lambda)$ dan vektor eigen $(v)$ dari matriks kovarian.

5. Mengurutkan vektor eigen berdasarkan dengan besarnya nilai eigen masing-masing vektor.

6. Menghitung matriks proyeksi PCA(Wpca) yaitu dengan mengalikan nilai deviasi dengan vektor eigen dan menormalisasikan hasilnya.

$V^{\prime}=\phi \cdot v$

$W_{P C A}=\frac{V^{\prime}}{\left\|V^{\prime}\right\|}$

7. Mengambil N-C komponen Wpca yangdiperlukan untuk mengkonstruksi fisherface.

\section{Perhitungan FLD}

Perhitungan FLD dilakukan dengan langkah-langkah sebagai berikut :

1. Mentransformasikan training set ke dalam vektor kolom (face space, $\Gamma$ ).

2. Membentuk average face ( $\Psi)$ dari face space, dan nilai wajah rata-rata masing-masing kelas (class average face, $\Psi_{i}$ ).

3. Melakukan perhitungan matriks sebaran dalam kelas (within-calss scatter-matrix, $S_{W}$ ) dan matriks sebaran antar kelas (between-classscattermatrix, $S_{B}$ ).

4. Memproyeksikan matrikssebaran $\left(S_{W} \operatorname{dan} S_{B}\right)$ ke dalam matriks proyeksi PCA (Wpca).

$$
\begin{aligned}
& S_{W W}=W_{P C A}{ }^{T} S_{W} W_{P C A} \\
& S_{B B}=W_{P C A}{ }^{T} S_{B} W_{P C A}
\end{aligned}
$$

5. Menghitung nilai eigen dan vektor eigen dari matriks sebaran. 
6. Menghitung matriks proyeksi fisher dengan mengurutkan vektor eigen berdasarkan besarnya nilai eigen masing-masing vektor eigen dan mengambil komponen vektor eigen yang memiliki nilai eigen tidak nol. Untuk $C$ kelas, akan selalu didapat $\mathrm{C}-1$ vektor eigen yang memiliki nilai eigen tidak nol [3].

7. Menghitung matriks proyeksioptimal $\left(W_{O P T}\right)$.

8. Melakukan normalisasi pada matriks proyeksi optimal.

$$
W_{O P T}=\frac{W_{O P T}}{\left|W_{O P T}\right|}
$$

9. Menghitung bobot tiap fisherface terhadap masing-masing gambar wajah pada training set (face key, $U_{\text {database }}$ ) dengan memproyeksikan nilai deviasi face space terhadap averageface ke dalam matriks proyeksi optimal.

\section{Klasifikasi Identitas}

Klasifikasi identitas yang digunakan adalah dengan membandingkan bobot dari masing-masingfisherface pada gambar wajah pada training set dan gambar wajah masukan dengan menghitungjarak Euclidiannya. Langkah-langkah klasifikasi identitasadalah sebagai berikut:

1. Mengubah gambar wajah masukan menjadi vektor kolom $\left(\Gamma_{\text {input }}\right)$.

2. Menormalisasikan gambar wajah masukan terhadap nilai rata-rata training set (average face, $\Psi)$.

$$
\phi_{\text {input }}=\Gamma_{\text {input }}-\Psi
$$

3. Menghitung bobot fisherface pada gambar wajah masukan ( $U_{\text {input }}$ ), yaitu dengan memproyeksikan gambar masukan ke dalam matriks proyeksi optimal (Wopt).

$$
U_{\text {input }}=W_{\text {OPT }}^{T} \phi_{\text {input }}
$$

4. Menghitung jarak euclidian $\left(\mathrm{E}_{\min }\right)$ antarabobot input dan bobot training set ( $\left.U_{\text {database }}\right)$.

$$
\begin{aligned}
& \mathrm{E}=\mid U_{\text {input }}-U_{\text {database }} \|^{2} \\
& \mathrm{E}=\left(U_{\text {input }}-U_{\text {databas }}\right)^{T}\left(U_{\text {input }}-U_{\text {databas }}\right) \\
& C=\frac{U_{\text {input }}{ }^{T} U_{\text {database }}}{\left|U_{\text {inpul }}\right| \cdot \mid \| U_{\text {databasas }} \mathbf{I}}
\end{aligned}
$$

5. Mencari dan membandingkan jarak minimum $\left(E_{\min }\right)$ dengan satu nilai batas $(\theta)$. Sebuah wajah dikatakan cocok jika jarak minimumnya lebih kecil dari nilai batas yang diterapkan. Semakin kecil jarak minimum yang diperoleh, semakin besar kesamaan (similarity) gambar masukan dengan pasangan gambar pada training set. Nilai batas diperoleh dari hasil percobaan-percobaan hingga ditemukan satu nilai yang memuaskan.

\section{HASIL SIMULASI DAN ANALISA}

Simulasi dilakukan untuk menentukan besarnya threshold at au nilai batas yang digunakan pada proses klasifikasi identitas untuk pengenalan wajah. Data set yang digunakan dalam simulasi diambil dari kumpulan foto beberapa mahasiswa Fakultas Teknik Universitas Kristen Maranatha (UKM). Masingmasing individu dalam data set memiliki lima buah foto atau gambar dalam kondisi yangberbeda-beda, seperti kondisi normal, ketawa, dan penggunaan aksesoris kacamata. Banyaknya individu yang terdapat pada data set adalah 33 individudengan total gambar pada data set sebanyak 165 gambar. Masingmasing satu gambar dari setiap individudalam data set (total 33 gambar) diambil secara acak untuk digunakan sebagai gambar masukan atautest set pada simulasi dan sebanyak 132 gambar lainnya digunakan sebagai database atau training set (Gambar 4). Simulasi juga dilakukan dengan memberikan gambar masukan dari individu yang tidak terdapat pada training set.

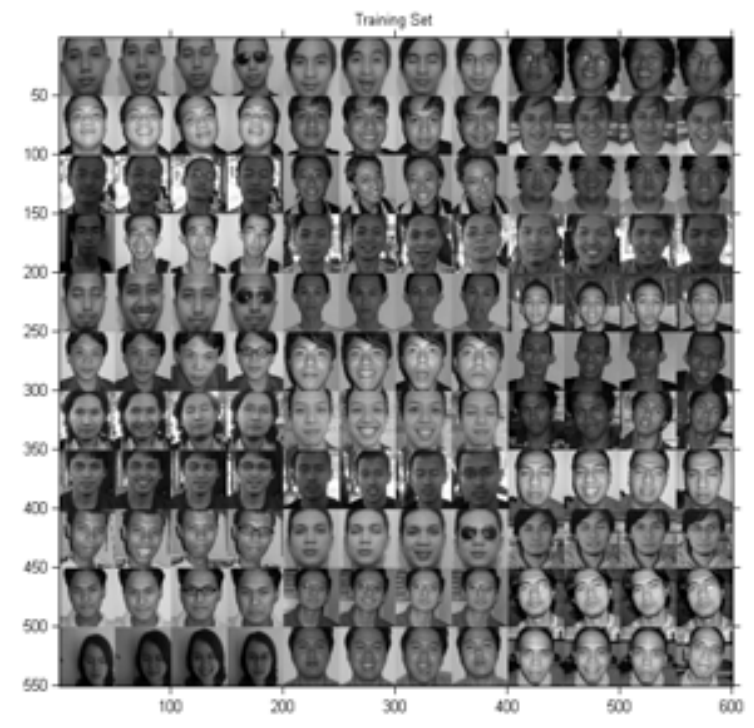

Gambar 4. Training Set

Untuk mengelompokkan gambar training set sesuai dengan masing-masing kelasnya, pemberian label pada masing-masing gambar dilakukan dengan memberikan nama pada masing-masing file gambar dengan aturan penamaan sebagai berikut : untuk gambar dengan kelas yang berbeda ataugambar dari individu yang berbeda, pemberian nama file gambar dilakukan dengan memberikan tiga hurufpertama nama file gambar yang berbeda dengan nama file 
gambar untuk kelas lainnya (sepertibudi, dudi,joko), karena program mendeteksi kelas yang berbeda dengan membandingkan 3 huruf pertamapada setiap nama file gambar training set. Untuk gambar training set yang merupakan satu kelas, diberikan nama yang sama untuk setiap file gambarnya akan tetapi dengan indeks yang berbeda (seperti budi_1, budi_2).

Training set tidak berpengaruh dalam proses deteksi wajah gambar input, akan tetapi merupakan kunci utama dalam proses konstruksi fisherface dan proses klasifikasi identitas.

Pada modul deteksi wajah, akan dilakukan pencarian posisi wajah dari gambar masukan, yangkemudian akan diekstrak (cropping) dan disesuaikan ukurannya (resize) dengan ukuran gambar pada training set. Contoh hasil yang didapat pada proses deteksi wajah ini adalah sebagai berikut:

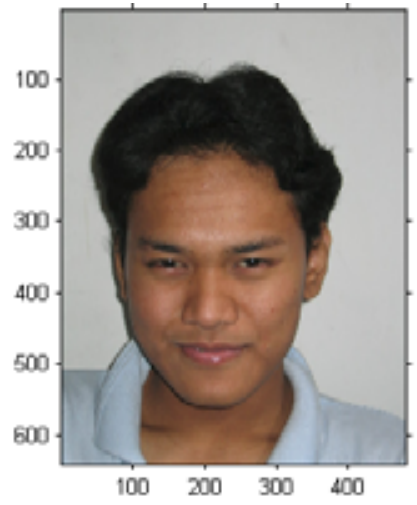

Gambar 5. Gambar Masukan

Pada Gambar 5 ditampilkan gambar masukan yang merupakan gambar input dengan level 24 bit (true color) yang nantinya akan dimasukkan ke dalam proses segmentasi kulit untuk menentukan piksel pada gambar yang memiliki intensitas warna kulit.

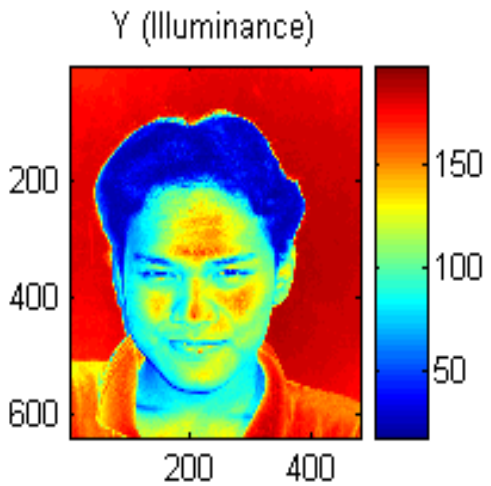

Gambar 6a. Komponen Y(Illuminance)

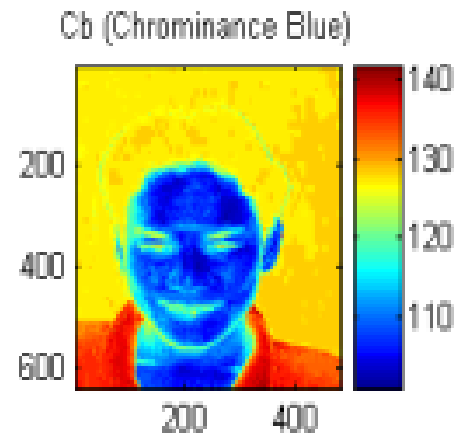

Gambar 6b. Komponen $\mathrm{Cb}$ (Chrominance Blue)

Pada Gambar 6 terlihat komponen chrominance blue (Cb) merupakan komponen dominan biru untuk warna kulit dan chrominance red $(\mathrm{Cr})$ merupakan komponen dominan warna merah. Dari informasi tersebut dapat dilakukan pemisahan antara bagian kulit dan latar belakang dengan melakukan pembatasan nilai intensitas warna pada kedua komponen warna tersebut.

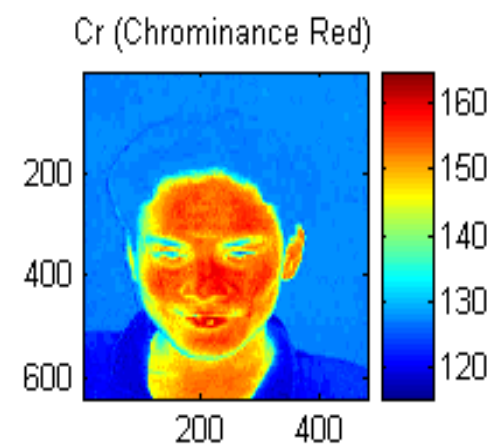

Gambar 6c. Komponen Cr (Chrominance Red)

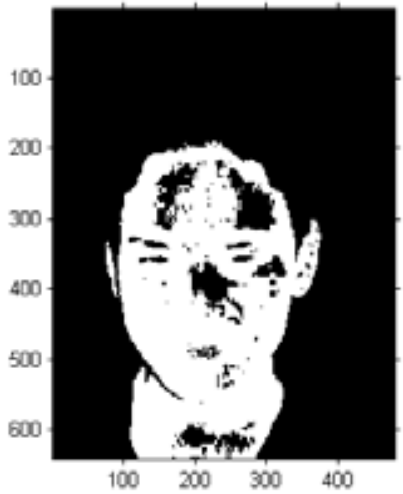

Gambar 7. Gambar Topeng Hasil Proses Segmentasi Kulit

Hasil proses segmentasi kulit merupakan gambar hitam putih yang disebut topeng dengan warna putih menunjukkan daerah atau piksel yangmengandung warna kulit. Pada gambar topengtidak hanya bagian wajah saja yang mengandung warna kulit yang 
muncul, namun bagian lain seperti latar belakang gambar dan bagian tubuh lain yang memiliki piksel dengan warna kulit juga ikut terdeteksi. Bagianbagian ini yang disebut dengan noise. Noise-noise tersebut akan sangat mempengaruhi dalam penentuan posisi wajah pada gambar. Oleh karena itu, sebelum dilakukan proses ekstrasi wajah dilakukan proses morfologi untuk membersihkan gambar hasil segmentasi kulit dari noise yang masih terdeteksi.

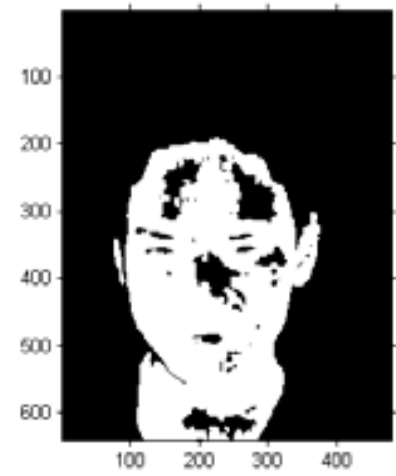

Gambar 8. Gambar T openg Hasil Proses Morfologi

Proses morfologi tidak akan menghilangkan seluruh noise yang terdapat dari gambartopeng. Noise yang memiliki radius lebih dari 2 piksel akan tetap terdapat pada gambar topeng. Oleh karena itu, untuk mendeteksi bagian yang benar-benar merupakan wajah, dilakukan proses region analysis, yaitudengan menghitung nilai Euler pada setiap bagian yangmasih terdeteksi pada gambar topenghasil prosesmorfologi.

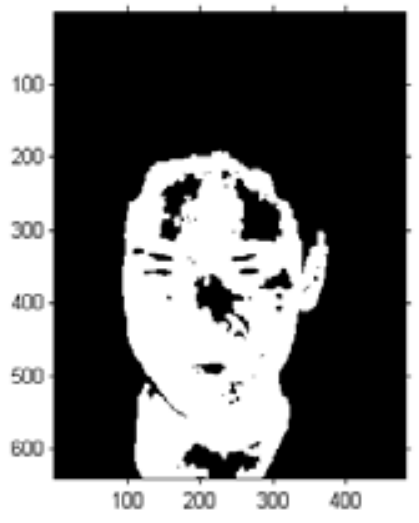

Gambar 9. Gambar T openg Hasil Proses Region Analysis

Setelah bagian wajah dari gambar topengdiketahui, proses yang akan dilakukan selanjutnya adalah menentukan atau mendefinisikan batas kotak wajah untuk kemudian dilakukan proses ekstrasi (cropping) pada gambar masukan sesuai kotak wajah yang terbentuk. Batas kotak wajah yangdigunakan adalah batas paling ujung (kiri, kanan, atas, bawah) setiap piksel warna putih pada gambar topeng Akan tetapi jika diperhatikan sekilas pada gambar topenghasil proses region analysis, didapat batasan kotak dari kepala hingga leher dengan bentuk persegipanjang Karena tujuannya untuk mendapatkan kotak wajah yang sesuai dengan dimensi gambar pada training set yang berupa kotak persegi, maka batasan kotak wajah yang diterapkan adalah panjang kali panjangdari bagian wajah yang terdeteksi pada gambar topeng hasil proses region analysis. Jika ukuran gambar pada training set tidak berdimensi persegi, misalnya persegi panjang dengan ukuran tertentu, maka pendefinisian kotak wajah harus berbentuk persegi panjangjuga dengan perbandingan panjang dan lebaryang sama dengan perbandingan panjang dan lebar gambar pada training set. Contoh hasil pembentukan kotak wajah pada gambar masukan adalah sebagai berikut :

Pada Gambar 10 terlihat kotak wajah yangterbentuk hampir sesuai dengan bagian wajah. Karena wajah yang terdeteksi berbentuk elips yang art inya lebih panjang bagian vertikal dibandingkan bagian horizontalnya, maka kelebihan posisi kotak disebabkan oleh kompensasi dari pendefinisian kotak wajah dengan dimensi persegi.

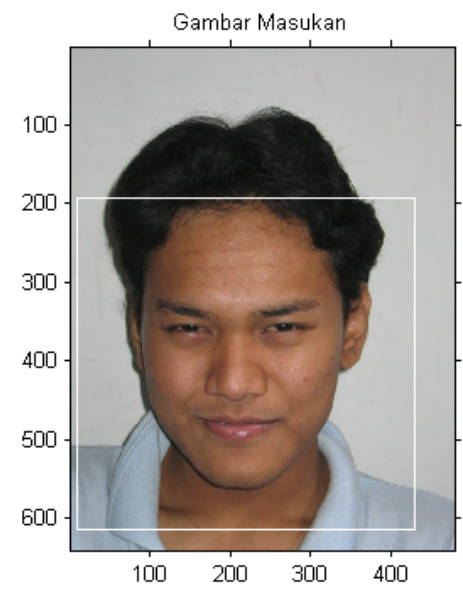

Gambar 10. Kotak Wajah

Setelah kotak wajah terdefinisi, selanjutnya dilakukan proses ekstrasi dengan melakukan cropping pada gambar masukan dengan level grayscale sesuai dengan batasan kotak wajah yangtelah terdefinisi dan proses penyesuaian ukuran (resize) gambar hasil cropping sesuai dengan dimensi gambar pada training set. Gambar wajah inilah yangakan menjadi keluaran dari proses deteksi wajah.

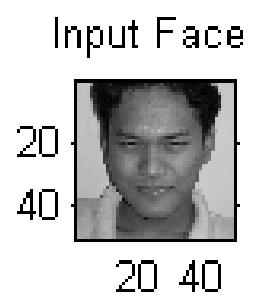

Gambar 11. Keluaran Proses Deteksi Wajah 
Konstruksi fisherface adalah pembuatan satu set fisherface dari suatu set gambar training Beberapa hasil gambar yang dapat dilihat selama proses konstruksi fisherface adalah sebagai berikut :

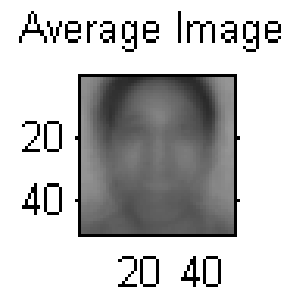

Gambar 12. Average Face

Average face ini adalah gambar wajah rata-rata dari keseluruhan gambar wajah dalam training set dan menyimpan semua informasi mengenai seluruh gambar dalam training set.

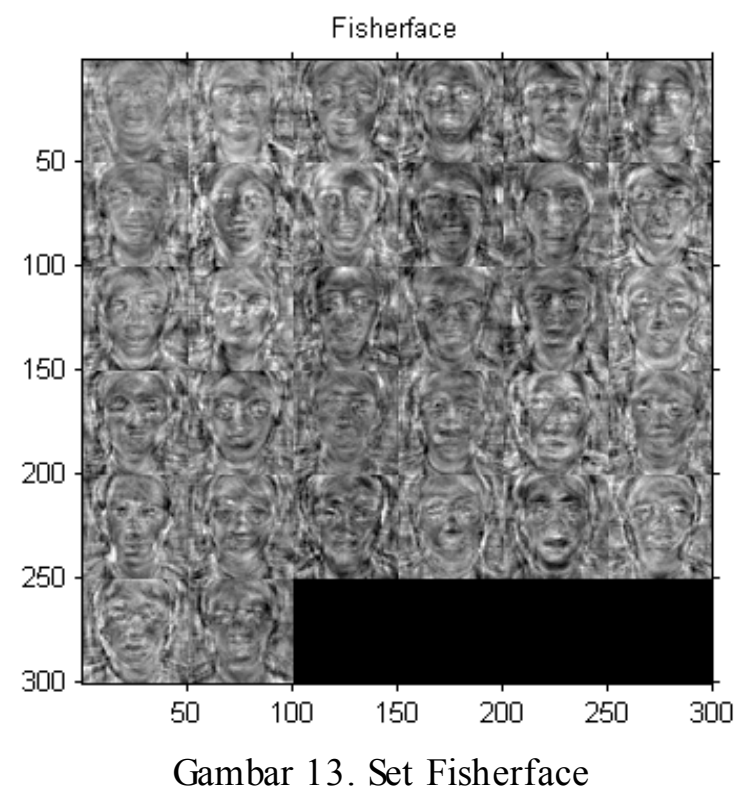

Fisherface ini sebenarnya merupakan suatu set vektor eigen dengan nilai eigen tertentu (matriksproyeksi optimal, Wopt) yang ditampilkan ke dalam gambar dua dimensi dengan level grayscale. Dari set fisherface ini setiap gambar wajah dapat direkonstruksi kembali dengan bobot yangberbeda dari tiap fisherface-nya. Dengan membandingkan bobot fisherface inilah dapat ditentukan identitasdari gambar masukan.

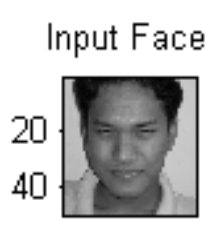

2040

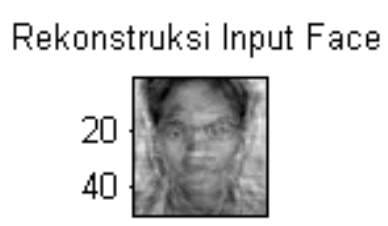

2040
Gambar 14. Rekonstruksi Gambar Wajah Masukan

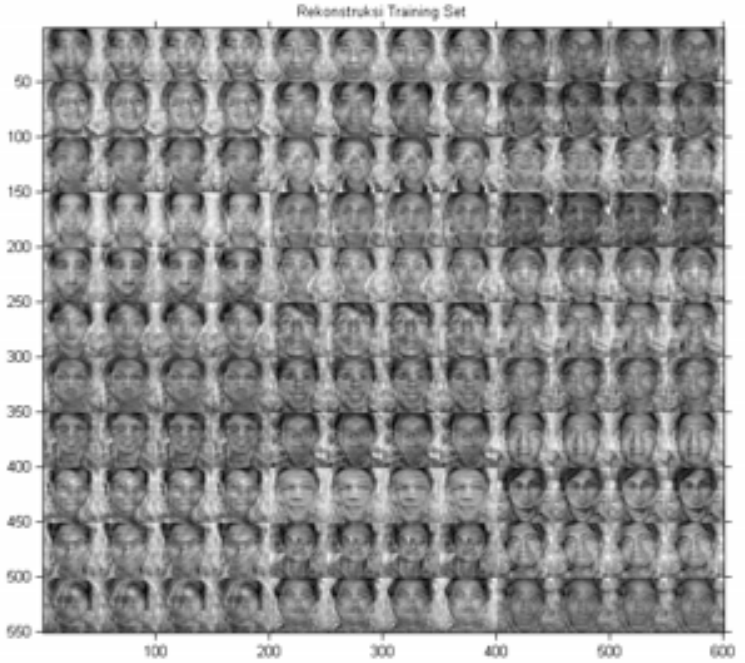

Gambar 15. Rekonstruksi Training Set

Terlihat sekilas pada gambar hasil rekonstruksi training set, walaupun gambar hasil rekonstruksi fisherface tidak menyerupai gambar aslinya, akan tetapi setiap gambar yang merupakan satu kelas memiliki gambar yang hampir sama. Hal ini berarti bahwa setiap gambar pada kelas yang sama yang diproyeksikan ke dalam kelas yangsama perbedaan gambarnya dapat dihilangkan atau direkonstruksi dengan menjadi satu gambar yang sama.

Seperti telah dijelaskan sebelumnya, prosesklasifikasi dilakukan dengan membandingkan bobot dari fisherface yang dibutuhkan untuk merekonstruksi setiap gambar wajah pada training set dengan bobot dari fisherface yang dibutuhkan untuk merekonstruksi gambar wajah masukan.

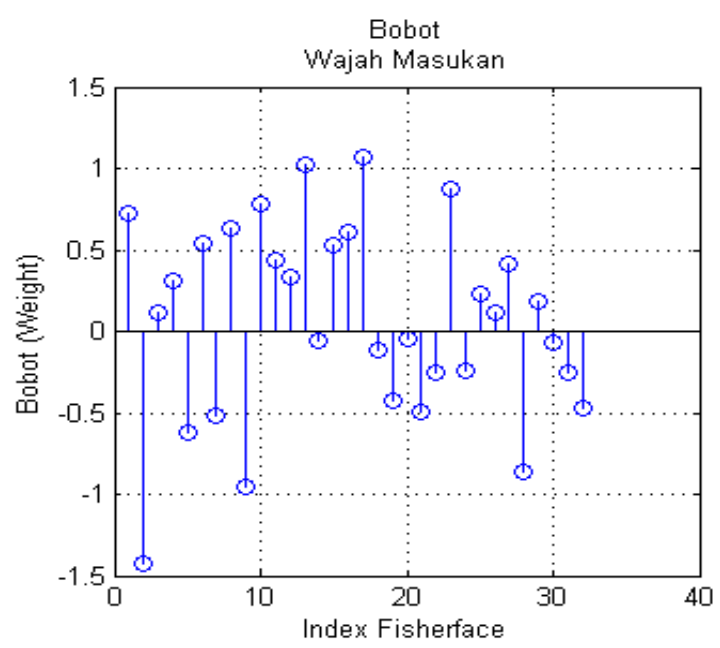

Gambar 16. Bobot Set Fisherface untuk Merekonstruksi Gambar Wajah Masukan

Metode perhitungan bobot yang digunakan adalah metode jarak Euclidian. Pada metode jarak Euclidian, dua buah gambar yang hampir sama akan memiliki jarak Euclidian mendekati 0. 


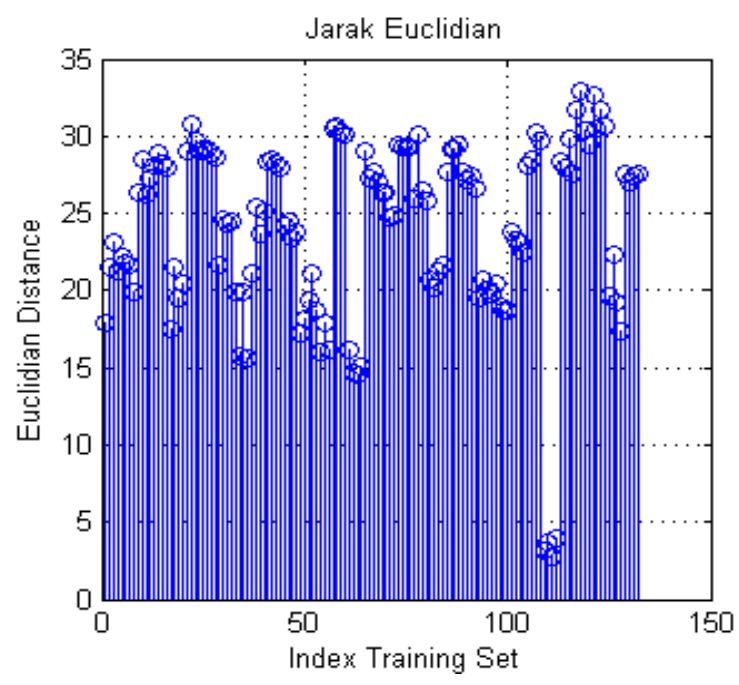

Gambar 17. Jarak Euclidian

Dari Gambar 17, jarak Euclidian minimum yang didapat adalah sebesar 1,15 untuk indeks gambar training set ke-111. Indeks gambar trainingset ke-111 merupakan kelas yang benar untuk mengidentifikasikan gambar masukan.
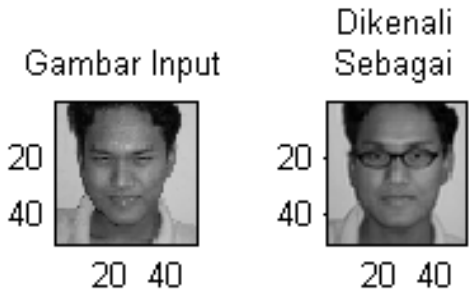

Gambar 18. Hasil Keputusan

Untuk mendapatkan keputusan yang tepat dalam mengidentifikasi gambar masukan, perluditentukan satu nilai batas yang dibutuhkan pada proses klasifikasi. Untuk itu dilakukan satuanalisa kesalahan (error rate analysis) dari hasil percobaan-percobaan yang telah dilakukan. Kesalahan yang dianalisa terdiri dari dua bentuk kesalahan, yaitu:

1. False acceptance rate (FAR) yangmenunjukkan kesalahan dalam mengenali identitas gambar masukan, baik itu kesalahan dalam mengenali identitas gambar masukan dari individu di luar training set yang terdeteksi sebagai individudi dalam training set, maupun kesalahan dalam mengenali identitas gambar masukan dari individu di dalam training set yang dikenali sebagai individu lain.

2. False rejection rate (FRR) yang menunjukkan kesalahan dalam menolak gambar masukan. Sebuah gambar masukan yang seharusnya dapat dikenali (ident itasnya terdapat di dalam training set) berubah menjadi tidak dikenali.
Besarnya nilai FAR dan FRR didapat dengan jalan mengubah-ubah nilai batas yang digunakan program dalam proses klasifikasi. Besarnya nilai FRRtidak terpengaruh oleh pengujian terhadap gambar masukan dari individu di luar training set, karena FRR hanya menghitung nilai kesalahan penolakan untuk gambar masukan dari individu yang terdapat di dalam training set.

Nilai batas yang digunakan pada program pengenalan wajah adalah nilai batas yang memberikan nilai kesalahan FAR sama dengan nilai kesalahan FRR atau yang biasa disebut dengan equal error rate (EER).

Tabel 1. Jarak Euclidian Minimum untuk Pengujian Individu di dalam Training Set

\begin{tabular}{lllll}
\hline No & Gambar & Jarak & Pasangan & gambar \\
& Masukan & Minimum & Status \\
Training Set & \\
\hline 1 & Abuy_2 & 2,41 & Abuy_3 & Benar \\
2 & Adi_2 & 1,35 & Adi_4 & Benar \\
3 & Andris_4 & 5,18 & Andris_5 & Benar \\
4 & Arbi_3 & 3,47 & Arbi_1 & Benar \\
5 & Ari_5 & 4,18 & Ari_3 & Benar \\
6 & Bobi_5 & 2,11 & Bobi_3 & Benar \\
7 & Budi_3 & 13,32 & Edi_4 & Salah \\
8 & Cath_5 & 9,76 & Hesron_5 & Salah \\
9 & David_4 & 2,19 & David_5 & Benar \\
10 & Dedi_3 & 9,95 & Dedi_1 & Benar \\
11 & Deni_3 & 13,77 & Deni_4 & Benar \\
12 & Doni_5 & 8,56 & Doni_4 & Benar \\
13 & Dude_2 & 1,98 & Dude_1 & Benar \\
14 & Edi_2 & 0,81 & Edi_4 & Benar \\
15 & Emil_5 & 7,27 & Emil_2 & Benar \\
16 & Ferry_5 & 4,39 & Ferry_3 & Benar \\
17 & Heri_3 & 6,19 & Heri_4 & Benar \\
18 & Hesron_4 & 2,32 & Hesron_2 & Benar \\
19 & Joni_3 & 4,19 & Joni_5 & Benar \\
20 & Jul_5 & 2,55 & Jul_4 & Benar \\
21 & Ken_5 & 7,32 & Ken_1 & Benar \\
22 & Kriss_3 & 2,64 & Kriss_4 & Benar \\
23 & Lexi_4 & 16,73 & Mike_1 & Salah \\
24 & Lutfi_3 & 9,61 & Lutfi_5 & Benar \\
25 & Mahar_3 & 2,79 & Mahar_4 & Benar \\
26 & Mike_3 & 5,86 & Abuy_5 & Salah \\
27 & Nurudin_2 & 4,40 & Nurudin_1 & Benar \\
28 & Oki_3 & 1,15 & Oki_5 & Benar \\
29 & Pandi_5 & 1,95 & Pandi_1 & Benar \\
30 & Santa_2 & 11,21 & Santa_1 & Benar \\
31 & Sinta_4 & 0,46 & Sinta_5 & Benar \\
32 & Widi_4 & 4,71 & Widi_3 & Benar \\
33 & Yedija_3 & 1,26 & Yedija_1 & Benar \\
\hline & & & & \\
& & &
\end{tabular}


Tabel 2. Jarak Euclidian Minimumuntuk Pengujian Individu di luar Training Set

\begin{tabular}{|c|c|c|}
\hline No & Jarak Minimum & $\begin{array}{c}\text { Pasangan Gambar } \\
\text { Training Set } \\
\end{array}$ \\
\hline 1 & 13,54 & 93 \\
\hline 2 & 15,36 & 127 \\
\hline 3 & 11,86 & 62 \\
\hline 4 & 10,35 & 1 \\
\hline 5 & 13,39 & 54 \\
\hline 6 & 10,14 & 99 \\
\hline 7 & 12,76 & 48 \\
\hline 8 & 13,2 & 56 \\
\hline 9 & 13,05 & 36 \\
\hline 10 & 15,94 & 35 \\
\hline 11 & 16,23 & 81 \\
\hline 12 & 17,94 & 35 \\
\hline 13 & 8,23 & 7 \\
\hline 14 & 15,89 & 7 \\
\hline 15 & 7,88 & 11 \\
\hline 16 & 20,50 & 10 \\
\hline 17 & 15,07 & 103 \\
\hline 18 & 7,79 & 104 \\
\hline 19 & 13,19 & 101 \\
\hline 20 & 12,94 & 9 \\
\hline 21 & 9,70 & 9 \\
\hline 22 & 16,11 & 11 \\
\hline 23 & 21,03 & 104 \\
\hline 24 & 13,71 & 1 \\
\hline 25 & 18,38 & 10 \\
\hline 26 & 13,85 & 79 \\
\hline 27 & 15,48 & 101 \\
\hline 28 & 15,35 & 9 \\
\hline 29 & 14 & 1 \\
\hline 30 & 13,65 & 127 \\
\hline 31 & 10,69 & 1 \\
\hline 32 & 17,46 & 1 \\
\hline 33 & 12,73 & 1 \\
\hline
\end{tabular}

Pada Gambar 19 dapat dilihat bahwa gambar masukan yang identitasnya tidak terdapat di dalam training set memiliki jarak yang lebih besar (grafik merah) jika dibandingkan dengan jarak untuk gambar masukan yang identitasnya terdapat di dalam training set (grafik biru). Nilai batas yang diinginkan adalah nilai batas yang sebanyak mungkin menolak grafik berwarna merah dan tetap menerima sebanyak mungkin grafik berwarna biru, dengan tetap memperhatikan kesalahan yang terjadi terutama kesalahan dalam mengidentifikasi. Program akan menolak gambar masukan jika jarak minimumnya melebihi nilai batas dan menerima gambar masukan jika jarak minimumnya lebih kecil dari nilaibatas yang digunakan dalam proses klasifikasi identitas.

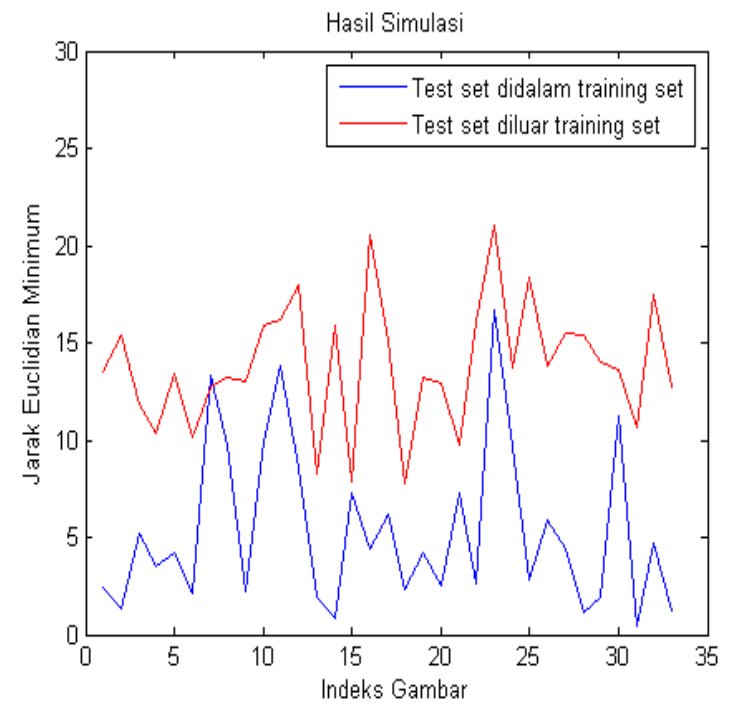

Gambar 19. Beda Jarak Euclidian Minimum untuk Gambar Masukan di dalam dan di luar Training Set

Tabel 3. Analisa Kesalahan Metode Jarak Euclidian

\begin{tabular}{ccc}
\hline Threshold & $\begin{array}{c}\text { False Rejection } \\
\text { Rate (FRR), \% }\end{array}$ & $\begin{array}{c}\text { False Acceptance } \\
\text { Rate (FAR), \% }\end{array}$ \\
\hline 0 & 100,00 & 0 \\
0,5 & 96,97 & 0 \\
1 & 93,94 & 0 \\
1,5 & 84,85 & 0 \\
2 & 78,79 & 0 \\
2,5 & 66,67 & 0 \\
3 & 57,58 & 0 \\
3,5 & 54,55 & 0 \\
4 & 54,55 & 0 \\
4,5 & 42,42 & 0 \\
5 & 39,39 & 0 \\
5,5 & 36,36 & 1,51 \\
6 & 33,33 & 1,51 \\
6,5 & 30,30 & 1,51 \\
7 & 30,30 & 1,51 \\
7,5 & 24,24 & 4,54 \\
8 & 24,24 & 6,06 \\
8,5 & 24,24 & 6,06 \\
9 & 21,21 & 7,57 \\
9,5 & 21,21 & 9,09 \\
10 & 12,12 & 12,12 \\
10,5 & 12,12 & 13,63 \\
11 & 12,12 & 13,63 \\
11,5 & 9,09 & 15,15 \\
12 & 9,09 & 15,15 \\
12,5 & 9,09 & 19,69 \\
13 & 9,09 & 25,75 \\
13,5 & 6,06 & 33,33 \\
14 & 3,03 & 34,84 \\
14,5 & 3,03 & 34,84 \\
15 & 3,03 &
\end{tabular}




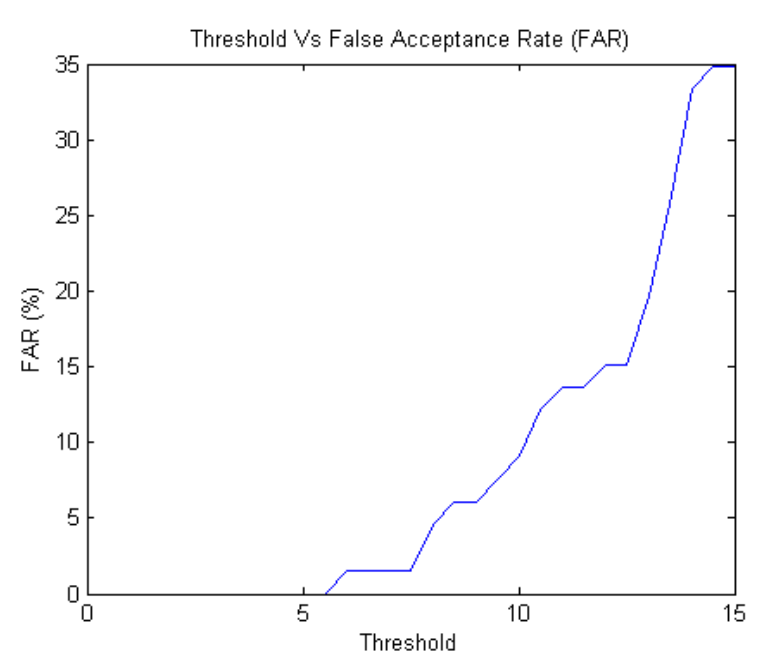

Gambar 20. False Acceptance Rate (FAR) Jarak Euclidian

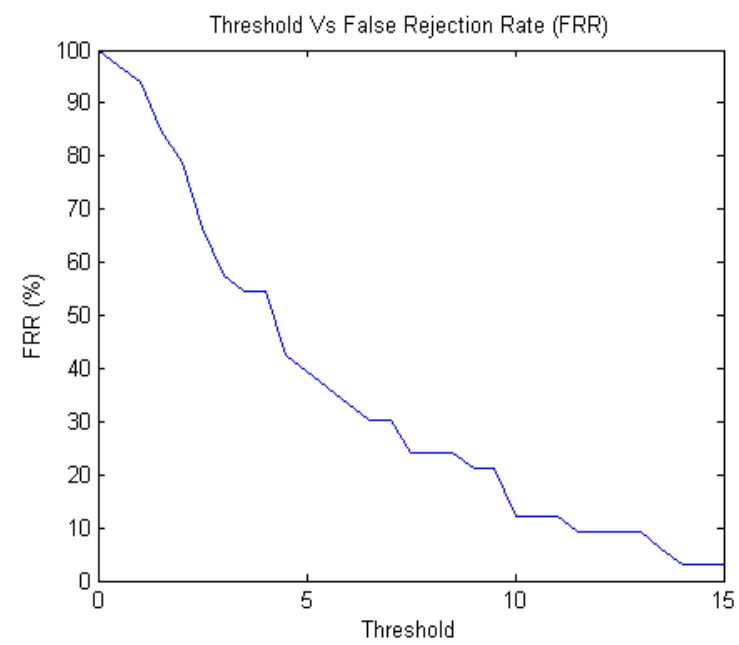

Gambar 21. False Rejection Rate (FRR) Jarak Euclidian

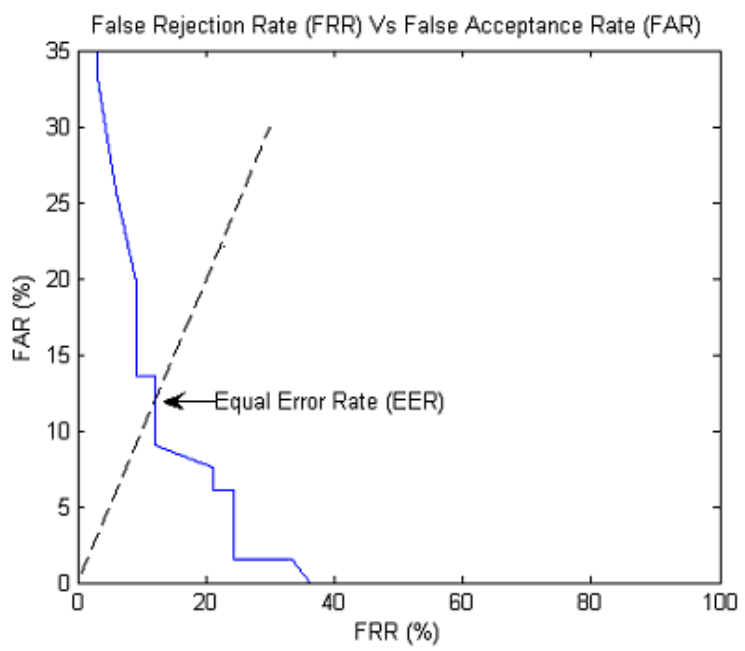

Gambar 22. Equal Error Rate (EER) Jarak Euclidian
Dari Gambar 22, nilai EER yang diperoleh adalah sebesar $12,12 \%$, yaitu saat nilai batasyang digunakan adalah 10,5, dengan besarnya kesalahan sebesar $18,18 \%$. Dari grafik tersebut masih bisa didapatkan satu nilai kesalahan yang lebih baik, tetapidengan kompensasi besarnya nilai FAR yang lebih besar, yaitu saat nilai batas yang digunakan adalah 7,5, sehingga menghasilkan nilai FRR $=24,24 \%$ dan FAR $=1,53 \%$ serta besarnya kesalahan berkurangmenjadi 13,64\%. Dalam penerapannya di kehidupan nyata, nilai kesalahan FAR lebih penting dibandingkan dengan nilai kesalahan FRR, karena lebih baik melakukan verifikasi berulang kepada individuyang berada di dalam training set

tetapi tidak dikenali daripada meloloskan individudi luar training set dan dikenali sebagai individuyang berada di dalam training set .

\section{KES IMPULAN}

Dari beberapa percobaan yang dilakukan dapat diambil kesimpulan sebagai berikut:

1. Proses deteksi wajah berbasis warna kulit dengan melakukan pembatasan nilai intensitas komponen chrominance warna berhasil melakukan deteksi lokasi wajah seseorang dalam suatu gambar dengan latar belakang gambar tertentu.

2. Metode fisherface yang digunakan dalam proses pengenalan memberikan akurasi yangcukup baik sebesar $81,82 \%$ dengan nilai kesalahan (error rate $)=18,18 \%(E E R=12,12 \%)$ yang diuji terhadap 66 gambar masukan dalam kondisi yang berbeda-beda, seperti ekspresi, cahaya, dan pemakaian aksesoris pada wajah.

3. Dalam proses klasifikasi dapat dipilih satunilai batas yang mampu memberikan nilai kesalahan yang lebih kecil, namun dengan kompensasi nilai False Rejection Rate (FRR) yang lebih besar. Untuk metode jarak Euclidian dengan memilih nilai batas sebesar 7,5, nilai kesalahan menjadi $13,64 \%$, tetapi nilai FRR naik menjadi 24,24\%.

\section{Ucapan Terima Kasih}

Melalui tulisan ini, penulis hendak mengucapkan terima kasih kepada Saudara Oki Pamungkas Arief, ST. yang telah membantu penulis di dalam pelaksanaan penelitian ini. 


\section{DAFTAR PUSTAKA}

[1] Zhao W., Chellapa R., Phillips P.J., "Face recognition: survey paper", ACM Computing Surveys ,Vol. 35 No. 4, 2003.

[2] Ming-Hsuan Yang and Narendra Ahuja, Detecting Human Faces in Color Images, Beckman Institute and Department of Electrical and Computer Engineering, University of Illinois at Urbana-Champaign.

[3] Mohsin, Waqar, Ahmed, Noman, Mar, Chungtse., Face Detection Project, Department of Electrical Engineering, Stanford University, May 2003.

[4] Ming-Hsuan Yang, David J. Kriegman, and Narendra Ahuja, "Detecting Faces in Images: A Survey", IEEE Transcactions on Pattem Aanalysis and Machine Intelligence, Vol. 24, No. 1, January 2002. 